\title{
РЕЛІГІЙНО-ПРАГМАТИЧНИЙ ІНДИВІДУАЛІЗМ ЯК РЕЗУЛЬТАТ ФІЛОСОФСЬКО-ПРАВОВОЇ ІДЕОЛОГІЇ СЕРЕДНЬОВІЧЧЯ
}

Пилипишин П. Б.

У науковій статті досліджено релігійно-прагматичний індивідуалізм, який виник на основі філософсько-правової ідеології Середньовіччя. Проаналізовано історичні аспекти виникнення індивідуалізму в добу Середньовіччя. 3 урахуванням проведеного аналізу філософсько-правових ідей мислителів даної доби зроблені висновки, що розвиток індивідуалізму на різних стадіях його формування був різним, однак його існування $\epsilon$ беззаперечним.

Ключові слова: індивідуалізм, Середньовіччя, теологія, природне право, позитивне право.

В научной статье исследован религиозно-прагматиче ский индивидуализм, который возник на основе философско-правовой идеологии Средневековья. Проанализированы исторические аспекты возникновения индивидуализма в эпоху Средневековья. С учетом проведенного анализа философско-правовых идей мыслителей данной эпохи сделаны выводы, что развитие индивидуализма на разных стадиях его формирования было разным, однако его существование является бесспорным.

Ключевые слова: индивидуализм, Средневековье, теология, естественное право, позитивное право.

Pylypyshyn P. B. Religious-pragmatic individualism, which emerged based on the philosophical and legal ideology of the Middle Ages

The scientific article explores the religious-pragmatic individualism, which emerged based on the philosophical and legal ideology of the Middle Ages. It is analysed the historical aspects of the emergence of individualism in the Middle Ages, and it is substantiated its distinct dependence on the theological worldview of this time. Christianity has become that civilizational matrix for individualism thanks to which a world outlook begins, within the framework of which each individual person begins to understand and realize his right to recognition. Christianity is the process of transforming a Western European person into a personality who has conceived one's belonging not only to the Christian world but also to own condition.

Based on the analysis of philosophical and legal ideas of thinkers of the specified epoch, we concluded that the development of individualism at different stages of its formation was diverse. So, even within the same period, one can observe a different vision of a person and one's place in the world. In particular, Saint Augustine's worldview is irrational, where the soul has feelings of love, repentance, conscience, patience, compassion, humanity, etc., and Thomas Aquinas's worldview is rational since the mind has primacy over the will.

The article has highlighted the major philosophical-legal ideas and facts which, in our opinion, formed the basis of Christian individualism: the conversion of Christianity to each individual, personalization, emphasis on one's features and ingenuity; understanding of the unique personality of a person through their manifestation in the moral life of a person, in his actions, choice; human awareness of himself as an autonomous individuality; metaphysical substantiation of the uniqueness

( Пилипишин П. Б., 2020 of a person as a personality and its independent self-esteem; affirmation by a person of free will and personal responsibility; disclosure of individuality through the principle of individual retribution for sins, self-salvation, spirituality; cognition of a man through spirituality, which proclaimed man as a self-valuable, human being.

Key words: individualism, Middle Ages, theology, natural law, positive law.

Постановка проблеми та їі актуальність. Проаналізувавши наукову літературу, присвячену індивідуалізму, можна зустріти багато аргументів щодо заперечення існування індивідуалізму в епоху Середньовіччя. На підтвердження цієї думки висуваються цілком правдиві аргументи, зокрема: в епоху Середньовіччя людське прагнення в самовизначенні і самоврядуванні - це людська гординя та гріховність; самостійність, самоврядування, самоповага, самовпевненість - абсолютно неприпустимі; придушення в людині природних прагнень та бажань; соціально-політична система феодалізму, феодальна власність, станова замкнутість дозволяли проявити індивідуалізм лише до предметного світу; індивідуальне трактувалося як щось минуще, а тому вічне має перевагу над ним; західноєвропейський чоловік підкоряв особисте, індивідуальне загальному, колективному, загальноприйнятому релігією; одиничність як цінність у середньовічній філософії права не приймається; відмова від себе - основна риса середньовічної особистості; прагнення загальної схожості стало масовим процесом, який за основу брав один прояв поведінки - типовість. У цій статті поставлена мета довести, що попри правдивість цих висловлювань, разом із тим середньовічна філософія права в особах провідних мислителів цієї епохи зробила неоціненний вклад у розвиток індивідуалізму, без якого не могло б йтися про сучасний стан дослідження індивідуалізму як провідної філософсько-правової течії.

Аналіз останніх досліджень і публікацій. Питання індивідуалізму хвилювало багатьох науковців, і не лише у сфері філософії права, а саме таких, як: А.С. Бандурка, В.П, Войтенко, Н.І. Гібадулліна, Н.С. Глущенко, О.В. Грищук, О.М. Корх, Х.Т. Слюсарчук, Т.Д. Федорова, 3.О. Шевченко та інші. Однак, незважаючи на значні здобутки вчених, ґрунтовного вивчення саме середньовічного індивідуалізму не відбувалося.

Мета статті - розкрити філософсько-правові особливості індивідуалізму в Середньовічну епоху.

Виклад основного матеріалу. На формування індивідуалізму на Заході мали вплив специфічні умови розвитку Заходу, як-от: історико-культурні, географічні, спільні цивілізаційні, соціальні, політичні, економічні, релігійні, культурні ознаки для країн Європи. Найбільш вагомим системоутворюючим фактором індивідуалізму можна вважати цивілізаційний. Одним із 


\section{Актуальні проблеми історико-правової науки}

найбільш важливих факторів цього формування стала релігія, яка задавала моральні орієнтири і моральні зразки поведінки в суспільстві. Християнство стало тою цивілізаційною матрицею для індивідуалізму, завдяки якій починається світоглядний поворот, у межах якого кожна окремо взята особистість починає розуміти й усвідомлювати свої домагання на визнання. Однак спершу в основі середньовічного типу ставлення людини до світу лежить феодальна власність, станова замкнутість, панування християнства, а також духовна цілісність, що припускає переважання вічного над індивідуальним, минущим. I лише після XIII століття цей процес почався 3 перетворення західноєвропейської людини в особистість, яка усвідомила свою належність не лише до християнського світу, але й до свого стану. На це вплинув економічний фактор, який породив становлення буржуазних відносин, де людина, відчуваючи зростання своєї значущості, а також самостійності у сфері економіки, почала прагнути до особистої свободи. Стан, колектив йдуть на другий план, а середньовічна людина шукає нового змісту життя [1, с. 72].

В епоху середньовіччя починає зароджуватися ще одна важлива для індивідуалізму філософсько-правова ідея - ідея прав людини. Індивід перед державою не повинен схилятися, усвідомлюючи свій вінець прав, на які держава не може зазіхнути, тому що їх законність випливає із цінності самої особистості. Основою прав людини $є$ закон природи, так би мовити, людська сутність і вічний закон - вічні відносини, які регулюють порядок сутностей відповідно до вказівок одвічно існуючої мудрості. Ось деякі прерогативи індивідуума, які з'являються в декларації прав людини XIII століття: право на збереження свого життя, право вступати в шлюб і ростити дітей, право розвивати свій інтелект, право на навчання, право на правду, право жити в суспільстві. Таким чином, наприкінці існування середньовічної культури філософія права виправдовує з етичної точки зору концепцію цінності індивідуума перед центральною владою. Але ми бачимо водночас, що вона також носить феодальний характер. Адже і лицар, і барон, і васал, і громадянин два минулі століття були поглинені ідеєю жити своїм власним життям [2, с. 185-190].

У Західній Європі в християнський період розвитку ідеї індивідуалізму проглядаються у релігійних філософів Аврелія Августина, Аніція Северина Боеція і Фоми Аквінського [3, с. 26]. Успадкована від античних філософів ідея невмирущості душі найбільш ґрунтовно розробляється теологією. У теології віра протилежна знанню й оголошена невід'ємною і основоположною властивістю людської душі. У релігійно-філософській системі найбільшого середньовічного філософа, найвизначнішого представника західних «батьків церкви» Аврелія Августина Блаженного біблійний світогляд пов'язаний з тими положеннями неоплатонізму, які не суперечать християнському віровченню. Центральний пункт філософської системи Аврелія Августина Блаженного - Бог, тому вона виключно теоцентрична [4, с. 30]. Ключове для сучасного розуміння індивідуалізму поняття особи було введено у філософський обіг через християнство, зокрема одним із перших отців церкви Августином. «Бог християн - не якийсь світовий Логос Геракліта або живий, одушевлений і розумний Космос Плотіна, він $€$ саме Особа, Персона. Тому і людина, створена за образом і подобою Творця, - теж особа. Суттєвим ii атрибутом $€$ свобода, зокрема свобода волі, хоча через гріхопадіння вона втратила первозданну єдність і повноту» [5, с. 54]. Його релігійна філософія мала за головну ідею пізнання Бога і Божої любові як мету і зміст людського духу. Свобода в Августина $є$ основою і початком самої людини та джерелом блага в суспільстві. Особливо наголошується, що людина повинна мати сумління, функціональне призначення якого «контролювати людську поведінку зсередини, а отже, бути своєрідним моральним законом, який Бог вкарбував у людському серці» [6, с. 85].

Для Августина центральним питанням філософії $\epsilon$ питання про людину: хто вона $\epsilon$, як їй жити? Вчення Августина про людину $\epsilon$ філософським доповненням до чотирьох основних християнських догматів: творіння, гріхопадіння, спокути і воскресіння. Догмат про творіння людини за образом і подобою Бога «змушував» Августина говорити про високу гідність людської природи і шукати в ній риси Божественного образу. I, навпаки, догмат про гріхопадіння приводив його до думки про невідворотну фізичну смерть. Інші два догмати нагадують людині про милосердя Боже та вічне життя [7, с. 40-42].

Креаціоністська доктрина Августина по-своєму трактує природу і людину. Душею володіє тільки людина, якою іï наділив Бог. Поділяючи тіло і душу людини, Августин визнає перевагу людської душі над тілом [4, с. 30]. На думку Августина, індивідуальність будьякої людини проявляється в її душі, а не в тілі. Вчення Августина про душу особливе тому, що він розглядає цю сутність душі не стільки в їі розумовій діяльності, скільки в діяльності вольовій. Цей позитивний момент у теологічному трактуванні волі людини опосередковує діяльність індивіда як таку. У цьому релігійно-ідеалістичному ключі воля має перевагу над людським розумом, оскільки активність людини проявляється не стільки в тому, що людина мислить, а скільки в тому, що людина має здатність до вольової діяльності. Августином вольова діяльність людини розглядається як ірраціональна, і тим не менше вона пов'язана зі свободою [8, с. 30]. За біблійним світоглядом Августина внутрішній світ, скоріше, залежить від почуттів і спонукань волі, ніж від діяльності розуму. Наділяючи душу не тільки розумною здатністю, але і здатністю до вольової діяльності, Августин вважає, що людина має свободу волі, але водночас підкреслює, що вона повністю $€$ частиною визначеного Богом плану порятунку. Августин у волі бачив характерну особливість людської істоти, тому що тільки вона визначає людську активність, а не мислення. Воля займає важливе місце у світогляді Августина, адже вона $є$ вирішальним фактором духовного життя. Августинівське трактування волі протилежне грецькому, де воля - це засіб, призначений для досягнення того, що розум пізнав. Отже, августинівське розуміння волі й пов'язане з ним питання про те, що $є$ правильним моральним вибором, залежить від його філософсько-теологічної точки зору на свободу волі людини і на проблему добра і зла [4, с. 31].

На думку сучасних дослідників, індивідуалізм Августина був би повним, якби не те, що людина, згідно з мислителем, діє вільно, але тільки суб'єктивно: все, що вона робить, робить через неї Бог. Людина не може бути самостійним джерелом добрих власних дій та слів 
через момент гріхопадіння, а тому вільна воля постійно штовхає людину на шлях гріха [9, с. 442]. Внутрішнє містить у собі ірраціональні імпульси, гріх, провину і пристрасне бажання до порятунку. Августин, на відміну від стоїків, не вірить, що людина може сама керувати своїм внутрішнім життям, адже ми потребуємо милості й «надлюдської» допомоги [4, с. 30].

У філософії Августина спостерігаємо певні протиріччя. Так, з одного боку, людина наділена індивідуальною свобідною волею, нехай і гріховною, а з іншого - проповідуючи крайній аскетизм, Августин вимагає заради служіння Богові відмови від власної особистості. На думку Августина, весь зовнішній світ формується на крайньому індивідуалізмі, а саме на егоїзмі, на любові людини до самої себе [10, с. 86]. Тому, як вважає 3.В. Шевченко, релігійний індивідуалізм Августина не $\epsilon$ гуманним, оскільки «заради індивідуального спасіння саме любов до Бога повинна наповнювати все життя людини, витиснути любов до людини, оскільки вона хибна - спрямована на тимчасове, тлінне». Індивідуалізм Августина, як бачимо, $\epsilon$ втіленням суто релігійно-прагматичного, аскетичного світобачення, де індивідуальне спасіння та надія на вічне життя передбачає відмову від своєї власної природи, від усього земного [11, с. 20].

У творах Аврелія Августина ідея індивідуалізму розглядалась через призму вищої Божої справедливості. Справедливість для нього - це не доброчесні поступки, як учили стоїки, не відповідність людських дій законам всесвітнього розуму, справедливість можлива лише в граді Божому. Град Божий у Августина - це ідеальний грецький поліс, в якому панують християнські засади. У своїй праці «Про град Божий» Августин зафіксував визначальну ідею протиставлення божественного (jus divinum) і людського, світського (jus humana) законів. Божественний закон - це і предмет дослідження, і предмет віри людини, який записаний у Біблії - найважливішій цінності, яка відображає Божу волю. Незмінний закон природи, або природний закон Августин помістив на друге місце. Природний закон - це еманація, породження божественного закону, оскільки природа - це творіння Бога. Світський (людський) закон (наприклад, римське право періоду християнської Римської імперії) в Августина на третьому місці [12, с. 130].

А.С. Боецій, як й інші мислителі християнської епохи, вважав, що першим і єдиним, незмінним і вічним $€$ буття Бога. Буття Бога уявляється ним як тотожне Благу. І, відповідно, лише життя в Бозі $\epsilon$ шляхом до справжнього буття. Гуманні відносини між людьми - це відносини, засновані на любові та бажанні самопожертви [3, с. 27].

У представника середньовічного вільнодумства П’єра Абеляра, засудженого церквою за єресь, поняття індивідуалізму виходить із поняття наміру. За його переконаннями, вся діяльність людини визначається ііі намірами, і жоден іï вчинок не може бути ані добрим, ані злим. У книзі «Пізнай самого себе» Абеляр зазначає, що $є$ тільки один гріх - гріх проти власної свідомості, проти власних переконань індивіда. Таким чином, філософ стає на захист індивідуалізму, незважаючи на певні, жорстко усталені догми того часу. Відповідно до цього Абеляр вважає, що язичники, які переслідували Христа, не є грішниками, оскільки їхні дії не знаходились у протиріччі з їхніми переконаннями. Не були грі- ховними й античні філософи, хоча вони не були прибічниками християнства, але діяли відповідно до власних високих моральних принципів. За Абеляром, людина не повинна бути рабом релігії, не сприймаючи їі розумом, а звичкою. Людина не повинна механічно, неусвідомлено повторювати те, що не відчуває власним серцем, свідомістю. Отже, оскільки абсолютний іманентний закон моральності, за Абеляром, конституюється індивідуальною свідомістю, його філософію іноді називають суб'єктивістською (індивідуалістичною). У зв'язку із цим доречно згадати й іншого єретика Іоанна Скота Еріугена, який вважає, що Бог - джерело добра і може схиляти людину до добра лише умовно, оскільки Бог вищий за час, він поза часом. Основне призначення людини - бути вільною (у цьому випадку індивідуалізм постає в контексті свободи). Людина сама обирає шлях між добром та злом, вона вільна [11, с. 19-21].

Тома Аквінський, як Августин і Боецій, у своїх працях розмірковував про Боже буття. Бог у Аквінського $\epsilon$ вищим благом. Справжній правдивий Образ Бога знаходиться в розумній людській істоті. Оскільки Бог - це буття, яке має усталений лад та ієрархію, то моральність, розмірковує Аквінський, полягає в наслідуванні цього ладу, як у житті: особистісному і соціальному. За Т. Аквінським, Бог $\epsilon$ найвищою метою християнства, до якої треба прагнути все своє життя, підлаштовуючи до неї всі свої справи та помисли [13, с. 359].

У XIII ст. в Європі знову стали широко відомими праці Арістотеля, які дуже вплинули на розвиток філософії права та стали базисом для розуміння Томою Аквінським. Однак учення Томи Аквінського $є$ синтезом не тільки арістотелівської та християнської філософії, але і стоїчної. Ця система, відома як томізм, стала офіційною доктриною католицької церкви та кульмінацією природно-правової традиції. Його завдання полягало в тому, щоб доказати: людське право - здобуток християнського віровчення [12, с. 137]. Аквінський від арістотелівської філософії взяв ідею того, що людина $\epsilon$ «тварина товариська і політична» за своєю природою. Оскільки індивід сам на сам задовольнити свої потреби не в змозі, то люди почали реалізовувати свої прагнення до об'єднання. Така природна причина стає початком до утворення політичної спільноти - держави. Утворення державності аналогічне створенню світу Богом, де в державі, як і у створеному Богом світі, має існувати упорядкованість, певна ієрархія, організованість і стрункість. Метою державності $\epsilon$ «загальне благо», забезпечення умов для гідного, розумного життя, яке неможливо без ієрархії: нижчий повинен підкорятися вищому [14, с. 286].

Для Томи Аквінського особистість - найблагородніша у всій живій природі, а інтелект - завжди особистий інтелект. «У Бога інтелект $\epsilon$ сутність, в людині - потенція сутності. Мислить не інтелект, а людина за допомогою інтелекту. Включення інтелекту, розуму в конкретну душевно-тілесну індивідуальність і заперечення іiі абсолютності, як випливає з християнства, поєднується в томізмі з твердженням примату інтелекту над волею. Розум вище волі, але любов до Бога важливіше пізнання Бога. Тома Аквінський бачив у людині суспільну істоту, здатну розрізняти добро і зло» [15, с. 46-47].

Згідно з Аквінським, двома головними функціями людської душі $\epsilon$ пізнання і воля. При цьому воля розуміється як активна сила, наступна за пізнанням. Пізнання 


\section{Актуальні проблеми історико-правової науки}

$\epsilon$ первинним, а воля розуміється як імпульс, що залежить від того, що встановлено за мету. Ці міркування, з одного боку, $\epsilon$ основою філософської антропології Томи Аквінського, з іншого ж - протилежні августинівській концепції, згідно з якою душа являє собою незалежну від тіла духовну субстанцію. Це означає, що людина повністю ототожнюється 3 душею. Аквінський же вважає, що людина $є$ єдністю (compositum) тіла й душі. Душа $€$ формою тіла. Одночасно Тома Аквінський намагається довести, що характерною особливістю людини $є$ свобода. На думку Аквината, коренем усілякої свободи $є$ розум, оскільки довільні рішення вибору, які витікають із вільної волі людини, мають своє джерело в інтелектуально-пізнавальних органах. У своїй практичній діяльності людська особистість керується судженнями, що витікають з інтелекту, завдяки яким вона може робити вибір [4, с. 35]. Отже, очевидною ознакою суспільного статусу особи Тома Аквінський вважав свободу, яка витікає з раціональності, котра притаманна людині «за природою». Людина повинна слідувати замислам власної розумної природи, яка зумовлює іï свободу волі, для того щоб досягти спільного блага [16, с. 32-33]. Найбільш повно свобода, на його думку, реалізується у громадянському суспільстві, котре $\epsilon$ «владою вільних», а «кінцева мета громадянського суспільства - досягнення щасливого життя, що йому сприяють і державні, й особисті відносини». $[17$, с. 96] Така його концепція отримала назву етичного інтелектуалізму, заснованого на достатності знання про добро і зло, щоб чинити морально. Конечна підвалина Всесвіту, в тому числі й держави, дій людей, - розум. Закони, для розумної людини - це імперативні правила й норми поведінки, тобто що зобов'язують, їм варто підкорятися тому, що вони сприяють досягненню людиною ії головної мети. А головною метою для людини $\epsilon$ блаженство в загробному житті [12, с. 138].

Отже, філософія Томи Аквінського як одного з видатних представників схоластичного періоду середньовічної філософії має такі основні положення:

1) душа є причиною життя та включає в себе чуттєву й інтелектуальну складові частини;

3) людський інтелект спочатку є чиста потенційність, але при цьому володіє творчою активністю. Це означає, що розум людини за своєю природою не містить у собі форм існуючих речей, але лише сприймає, абстрагує їх, адже людський інтелект $\epsilon$ спершу подібним «дощечці, на якій нічого не написано»;

4) людина $€$ раціональною. У питанні про співвідношення мислення і волі - двох основних здібностей інтелектуальної душі - у протилежність августінівській традиції Тома стверджує про перевагу розумового початку над вольовим;

5) людина має свободу волі, яка дозволяє їй робити вибір між морально цінними вчинками і аморальними діями, що відхиляють від Бога;

5) душа людини нематеріальна, i це їй дозволяє пізнавати нематеріальне, тобто форму речей (іхні зміст, сутність);

6) душа $є$ форма людського тіла. Вона «оформляє» матерію людського тіла, індивідуалізує його, роблячи його чимось особливим і неповторним, визначає сутність людини;

7) людська душа може існувати самостійно, незалежно від тіла, вона непорушна і безсмертна. Причому такі здібності, як інтелект і воля, належать виключно душі як суб'єкту і після смерті тіла зберігаються в душі;

8) з'єднання душі й тіла в людині утворює «повну субстанцію», тоді як душа, відділена від тіла, утворює «неповну», недосконалу субстанцію [18, с. 24-28].

У середньовічному праві індивідуалістична традиція розвивалась у межах природного праворозуміння. Світовий, суспільний порядок підтримується законами правилами, відповідно до яких людина повинна діяти або утримуватися. Згідно з думкою св. Томи, закон повинен відповідати таким ознакам, як: а) розумність веління, б) відповідність загальному благу, в) компетентність органу, його який встановлює, і г) оприлюднення. Сам Тома встановлює чотири види законів, причому сутність деяких з них мало узгоджується із зазначеними ознаками. Ці види законів такі:

1) Вічний закон (lex aeterna) як вічний божественний розум, який править світом. Вічний закон проявляється сам собою у світі, але не оприлюднюється. Сумнів у компетентності законодавця тут неприпустимий.

2) Наступний за вічним законом іде закон природний (lex naturalis) як відображення вічного закону в розумних істот. Природний закон становить основу будь-якого позитивного законодавства та $€$ продуктом людини, яка завдяки своїй розумності розвинула далі закон вічний.

3) Розвиток основ природного закону випадає на долю позитивного, людського закону (lex humania). Подібно тому, як сам природний міститься in potentia в законі вічному, так природний закон містить in potentia закон позитивний. Необхідність покарання за вбивство ґрунтується на природному законі; питання ж про те, яке покарання буде призначено за цей злочин і в якому порядку - це компетенція позитивного закону.

4) Нарешті, божественний закон, який за суттю $\epsilon$ позитивним та виражений в Старому і Новому Завіті. Цей закон виник, тому що природа людини не завжди дає їй чітке уявлення про мету, до якої повинна прагнути їі діяльність, людські судження $\epsilon$ хиткі й не завжди правдиві, а людський закон - недосконалим [19, с. $116-118]$.

Августин Блаженний під природним правом розумів комплекс загальних начал, які випливають із вічного, божественного закону, виступають раціонально-етичною основою позитивного права та $€$ критерієм для його оцінки. Заперечуючи обов'язковий характер норм позитивного права, які суперечили природному праву, мислитель указував, що ані монархи, ані церква не повинні видавати закони, які суперечать природному праву, а самі такі закони не мають обов'язкової сили. Теолог був переконаний, що позитивне право $\epsilon$ нижчим від божественного і природного права, а несправедливий закон не відповідає поняттю закону взагалі. Тома Аквінський вважав правом лише те, що відповідало природному праву, тобто природне право - це критерій для позитивного. Позитивне право регулює дії й поведінку людей за допомогою покарання. Вчений, розмежовуючи справедливий і несправедливий закон, стверджував, що природний закон потрібний людям для усунення несправедливості [20, с. 135-136].

Отже, Тома Аквінський вважав, що вищим джерелом права слід визнавати право божественної волі, що це єдиний критерій справедливості, якому повинні підкорятись і звичайна людина, і правитель [21, с. 38]. 
Отже, передусім для нього право $\epsilon$ сферою правди, справедливості. Він вважав справедливістю, слідом за римськими юристами, постійне прагнення віддавати кожному своє. Позитивне право має місце, якщо зрівняння відбувається відповідно до людських законів. Головна думка в концепції права Т. Аквінського: правовим (позитивно-правовим) людське встановлення $\epsilon$ тільки тоді, коли воно не протирічить природному праву [14, с. 286].

Тома Аквінський виділяв основні складники природного права, які стосувалися безпосередньо людини: право на життя, свободу і щастя. Людина повинна прагнути до загального блага, не завдавати шкоди іншим, віддавати кожному своє, тоді ці права реалізуються. У даному випадку фактично в основі природного права мислитель бачив морально-етичні імперативи. Концепція Фоми Аквінського та його погляди на Божественне наділення людини такою якістю, як гідність, $\epsilon$ «великим внеском Фоми Аквінського і в цілому християнського гуманізму в концепцію невідчужуваних природних прав людини» [22, с. 83-86].

Таким чином, ми можемо простежити, як спільність у поглядах Августина Блаженного і Томи Аквінського, так і відмінність. Спільність їхніх філософсько-правових поглядів на індивідуалізм полягає в такому:

Бог - це особа, персона, вище та абсолютне благо; людина створена за образом та подобою Божою, тому вона неповторний індивід, особистість;

індивідуалізм проявляється через індивідуальність людської душі - душа індивідуалізує тіло, роблячи його особливим та неповторним;

ідея індивідуальності розкривається через призму

Божої справедливості;

індивідуалізм знаходить свій прояв через гідність, свободу, волю як особливості природного права; мета людського життя - щастя, яке полягає в пізнанні Бога і випробовуванні душі;

людина наділена сумлінням, яке повинне контролювати людську поведінку.

Разом із тим обидва мислителі - представники різних періодів часу. Так, Августин Блаженний - представник раннього Середньовіччя, а Тома Аквінський пізнього. Тому їхні філософсько-правові погляди дещо відрізняються. Особливо це стосується розуміння свободи та свободи волі. Так, згідно з Августином воля $\epsilon$ особливістю людського єства, а свобода волі - це здатність вибирати між добром і злом, гріховною поведінкою та богосхваленою. Однак свобода волі $\epsilon$ повністю частиною визначеного Богом плану порятунку. Через факт гріхопадіння людина не здатна вибирати добро, за неї це може зробити лише Бог. Тому в Августина людина водночас наділена свободою волі, але разом із тим вона не може здійснити правильний вибір через свою гріховність. Натомість Тома Аквінський розвинув бачення свободи та волі. Завдяки йому наприкінці епохи Середньовіччя трактування свободи волі набуло справжнього, дійсного змісту. Мислитель підтверджує, що ознакою правового статусу особи $\epsilon$ свобода, а трактування волі людини повинне розумітися як можливість розумного вибору. Саме розум, на думку мислителя, має більше значення під час прийняття правового рішення людиною, оскільки ії вільна воля черпає своє джерело в інтелектуально-пізнавальних органах. Таке твердження $\epsilon$ другою основною від- мінністю в поглядах християнських мислителів, тому що Августин мав протилежні погляди. Він відстоював позицію, згідно з якою воля - характерна особливість людської істоти, оскільки тільки вона визначає людську активність, а не мислення. Отже, світогляд Августина Блаженного $є$ ірраціональним за суттю, де душа наділена почуттями любові, каяття, сумління, терпіння, співчуття, людинолюбства тощо, а світогляд Томи Аквінського - раціональний, оскільки розум має примат над волею.

Тому, проаналізувавши філософсько-правові погляди двох визначних мислителів Середньовіччя Августина Блаженного та Фоми Аквінського, можемо стверджувати, що залежно від того, що християнські мислителі називали активною силою - Божественний розум чи його волю, виникли дві основні теїстичні моделі права - теїстично-раціональні й теїстично-волюнтаристські. Ці дві моделі належать до природно-правових концепцій права, тобто до правового натуралізму [12, с. 142-144].

Висновки. Проаналізувавши філософсько-правові ідеї Середньовіччя, можна стверджувати, що вони не завжди мали суто індивідуалістичний характер. Тому індивідуалізм в цю епоху можна було б назвати християнським або релігійно-прагматичним. Такий варіант індивідуалізму нас убезпечить від надмірної критики тих науковців, які не вбачають існування індивідуалізму в християнську епоху взагалі. Разом із тим така назва підкреслить і наше ставлення до індивідуалізму в Середньовіччі, адже ми погоджуємось, що поширення ідей індивідуалізму на різних стадіях існування традиційного суспільства було неоднаковим. Релігійно-прагматичний індивідуалізм не має «класичних» ознак, притаманних сучасному індивідуалізму, а тому той факт, що християнський індивідуалізм відмінний від теперішнього його розуміння, $\epsilon$ очевидним.

Проведений аналіз дозволив виділити основні філософсько-правові ідеї та факти, які, на нашу думку, лягли в основу християнського індивідуалізму:

- утворення теологічного права шляхом запозичення основних античних філософсько-правових ідей, здійснення їх трансформації;

розгляд права через призму вищої справедливості; поділ права на позитивне та природне;

поєднання раціонального та ірраціонального трактування способу прийняття правового рішення; зародження нових ціннісно-правових орієнтирів, переважно побудованих на християнському вченні; переворот у правосвідомості людини - Бог став особистістю, а людина і право - Його творінням;

- ідея «людини як центру всього»;

- ідея спорідненості, єдиного кореня людини і Бога реальності, через яку вона стає значущою для людини; себе;

особистий Бог - передбачає особисте ставлення до

звернення християнства до кожного індивіда, персоналізація, підкреслення його особливості;

розуміння неповторної індивідуальності особистості через прояв їх у моральному житті людини, в її вчинках, виборі;

усвідомлення людиною себе як автономної індивідуальності;

метафізичне обґрунтування унікальності людини як особи та її незалежної самоцінності; 
- з'єднання в людині моментів переживання, самосвідомості й інтуїтивного розуміння справжньої правової реальності;

- затвердження за людиною свободи волі та особистої відповідальності;

- під свободою малася на увазі передусім свобода від гріха і прокляття церкви;

- розкриття індивідуальності через принцип індивідуальної відплати за гріхи, індивідуального порятунку, духовності;

- пізнання людини через духовність, яка проголосила людину самоцінною, індивідуальною істотою;

- переорієнтація пізнавальної діяльності людини із зовнішньої сторони на внутрішню сторону людини;

- розуміння правових норм не як зовнішнього примусу, а через внутрішнє спонукання людини - совість; виділення основних складників природнього права, які стосувалися безпосередньо індивідуальності та людини: право на життя, свободу, щастя та вільний самобутній розвиток;

- втілення таких принципів середньовіччя у праві: теоцентризму, креаціонізму, антропоцентризму, гуманізму, персоналізму, рівності та справедливості, відповідальності та свободи волі.

\section{Література}

1. Войтенко В.П. Индивидуализм в России и на Западе: сравнительный концептуальный анализ : дисс. ... кандидата философских наук : 09.00.11. Ростов-на-Дону, 2014. 176 c.

2. Вульф Морис де. Средневековая философия и цивилизация / Пер. с англ. О.Д. Сидоровой. Москва : ЗАО Центрполиграф, 2014. 253 с.

3. Мелекаева И.К. Гуманизм и гуманные отношения в обществе : дисс. ... канд. филос. наук : 09.00.11. Ставрополь, 2004. 135 с.

4. Ботвинова А.В. Духовность и гуманизм в открытом обществе :Социально-философский анализ : дисс. ... д-ра филос. наук : 09.00.11. Москва, 2004. 320 с.

5. Бандурка А.С. Ціннісні засади та операційні принципи мультикультуралізму (аспект філософії культури) дисс ... канд. філос. наук : 09.00.04. Харків : Харківський нац. пед. ун-т ім. Г.С. Сковороди, 2012. 227 с.

6. Сливка С.С. Природне та надприродне право : у 3-х ч. Київ : Атіка, 2005. Ч. 1: Природне право: історико-філософський погляд. 224 с.

7. Хайруллин А.Г. Социально-философский анализ генезиса личности и ее свободы : дисс. ... докт. философ. наук : 09.00.11. Уфа, 2000. 259 с.

\section{Актуальні проблеми історико-правової науки}

8. Шаповалов В.П. Проблема генезиса человеческой свободы (Философско-методологические аспекты) : дисс. ... канд. филос. наук : 09.00.01. Владивосток, 2003. 196 с.

9. Чанышев А.Н. Курс лекций по древней и средневековой философии : учеб. пособие для вузов. Москва : Высш. шк., 1991. 512 с.

10. Бычков В.В. Идеал любви христианско-византийского мира. Философия любви : В 2 ч. / под. общ. ред. Д.П. Горского ; сост. А.А. Ивин. Москва : Политиздат, 1990. Ч. 1. С. 68-109.

11. Шевченко 3.В. Індивідуалізм як складова розвитку демократії : дис. ... канд. юрид. наук : 09.00.03. Київ, 2005. 228 c.

12. Кузнєцов В.І. Філософія права. Історія та сучасність : навчальний посібник. Київ : ВД «Стилос»: ПЦ «Фоліант», 2003. $382 \mathrm{c}$.

13. Блинников Л.В. Великие философы : учебный словарь-справочник. 2-е изд., перераб. и доп. Москва : Издательская корпорация «Логос», 1999. 432 с.

14. Сокол С.Ф., Козлов В.С. История политических и правовых учений : учеб. пособие. Минск : БИП-С Плюс, 2009. 527 c.

15. Философия. В 4-х томах. История философии : учебно-практическое пособие / под редакцией Ю.В. Еремина. Москва : МГУТУ, 2007. Ч. 1. 139 с.

16. Грищук О.В., Романинець М.Р. Формування та розвиток ідеї відповідальності людини в праві. Львів : Львівський державний університет внутрішніх справ, 2013. 268 с.

17. Тома Аквінський. Коментарі до Арістотелевої «Політики» / пер. з латини. Київ : Основи, 2000. 794 с.

18. Философия западноевропейского Средневековья : учебно-методическое пособие / под ред. проф. Микиртичан. Санкт-Петербург : СПбГПМА, 2007. 58 с.

19. Шершеневич Г.Ф. История философии права. Москва : Университетская типография, 1906. 461 с.

20. Грищук О.В., Попов Д.І. Застосування природного права при здійсненні судового угляду: філософсько-правові аспекти : монографія. Хмельницький : Хмельницький університет управління та права, 2014. 320 с.

21. Ковлер А.И. Антропология права : учебник для вузов. Москва : Издательство Норма, 2002. 480 с.

22. Философия права : учебное пособие / отв. ред. : Н.Н. Черногор, О.Ю. Рыбаков ; Ин-т законодат. и сравнит. правоведения при Правительстве РФ. Москва : Статут, 2018. 224 c.

Пилипишин П. Б., кандидат юридичних наук, докторант кафедри теорії та історії держави і права Хмельницького університету управління та права імені Леоніда Юзькова 